\title{
Practice Based Design for Learning at Work
}

\author{
J. Lundin ${ }^{1,2}$, L. Svensson ${ }^{1}$, U. Lundh-Snis ${ }^{1}$ and L. Pareto ${ }^{1}$ \\ ${ }^{1}$ University West, Trollhättan, Sweden \\ ${ }^{2}$ IT-University, Göteborg, Sweden
}

\begin{abstract}
Designing for learning at work in a manner that embraces the rich situatedness of practice involves a number of challenges in bridging normative and descriptive perspectives, as well as closing the gap between IS design theory and practice. In this paper, we propose a grounded approach that combines influence from learning theories with studies of existing learning practices. This approach could result in learning models, constituted of a sequence of learning activities that outlines the didactics of the workplace. The arguments are based on the empirical findings from an action-oriented research project in collaboration with six SME:s, and are illustrated through a e-learning model called “The Competence Kick-off”.
\end{abstract}

Index Terms-Competence development, IS design theory, Learning Activity, Learning Model.

\section{INTRODUCTION}

Learning at work is treated as an area of major interest from an organizational and a managerial perspective, as well as from a sociological and pedagogical. It is obvious that the knowledge of workers, and/or organizations, is understood as one of the keys to organizational success, from whatever perspective one might chose to grasp it.

The working life of today is by many scholars described as being on the verge of a new era. On the societal level this transformation have been described as entering a network society and information age [1], focus on innovation and creativity [2], communication driving new forms of business [3]. We can assume that this has an effect on how knowledge is produced and how people become competent at work - making research within this area particularly relevant. At present we know very little about how people become competent at work in the new workplace.

Workplace learning can be discussed both from an external perspective, that of the organization or managers, or from an internal perspective, of the practitioners engaging in work. From an managerial perspective learning at work is often described as problematic, difficult and insufficient, i.e. there is a great need for new and better ways for people to learn. This can be explained with understanding the business success as dependent upon the knowledge possessed and applied. Such a knowledge based perspective of the firm "postulates that the services rendered by tangible resources depend on how they are combined and applied, which is in turn a function of the firm's know-how (i.e., knowledge) " [4, pp. 108]. Knowledge is understood as the main resource and learning becomes the main process for increasing knowledge, i.e. increased success is dependent on increased, better, more efficient methods for learning.
Corporate learning is generally described as, at best, sufficient, but with a great possibility for improvement:

"It is no accident that most organizations learn poorly. The way they are designed and managed, the way peoples jobs are defined, and, most importantly, the way we all have been taught to think and interact (not only in organizations but more broadly) create fundamental learning disabilities." [5, pp. 18]. This potential for improvement is the motivation for the most influential literature on how knowledge and learning is managed in organizations (e.g. [6], [7], [8]).

From a perspective of the workers or practitioners, this might be formulated in a different way. Despite the changes in demands described in the beginning of this section they are still able to conduct their work in ways that are understood as competent. Empirical studies of learning at work continuously point to how the practice itself contains a variety of resources for learning and knowing. Lave \& Wenger understands the practice in itself as a system where learning is an "integral part" of all action [9]. In this perspective what work is about is in many ways to learn, to become more competent (e.g. [10],[11],[12]). However, only rarely these perspectives provide any guidance for improvement. It is within the fundament of these descriptive studies (sociology, workplace studies) that one cannot approach the practice with a normative approach.

The intersection of these perspectives deals with how organizations can be designed to allow, and afford learning at work. Learning takes place as part of the activities in the workplace in various, more or less organized forms. However, conceptualizing, defining and labeling this learning have proven to be fundamentally problematic. It is not so much the fact that employees are taking courses, engaging in traditional classroom activities, that create this problem, but rather what takes place in the workplace, as part of work. One way of describing this has been to talk about formal (training, classes), and informal (as part of work) learning [13]. This division has received criticism: what goes on at work is highly formalized, and that a division of learning as being either 'informal' or 'formal' is not in line with any theory of how we learn [14]. We learn in a multitude of situations be it school, work or anyplace else. It also emphasizes a division between schooling, as a place for learning, and the rest of life, as a place for applying what has been learned [15].

However, what we are talking about in this paper is not going to class, in a classroom, it is something else, something that takes place at work, and is understood (by the practitioners as a part of work). It might not be mundane, everyday activities, but it is work, and it is based in what work is about. It is part of the organized 
practice, but it is not necessarily organized as educational activities. However, it is certainly activities that are interesting to investigate and exploit from a learning perspective, we chose to call them learning activities.

In our research we aim to combine the recognition of the descriptive perspective appreciating the quality and elegance of learning activities at work, with a normative, design focused approach. And furthermore, we suggest a method for exploring these learning activities in the development of a didactic of the workplace.

The remainder of the paper outlines the theoretical foundations for understanding learning and design for learning, followed by a section that describes the empirical setting and some concrete results. The paper concludes with a model for how to do design work that capitalizes on the didactics of the workplace.

\section{THEORY}

\section{A. Learning at work}

Learning and knowing is here understood as an integral part of action that cannot be separated from human activity [9]. In everything we do, in any setting we participate in, there are always aspects of learning involved, and what is learned is inherently dependent on these settings. To many of us the idea that learning is part of, and dependent on everyday life is obvious, but, oddly enough, when looking at how training and education is arranged, and how IT support is designed, it becomes clear that competing conceptions of learning and knowing are common. Within design of IT support for learning at work the dominant tradition is one where learning is understood as knowledge transfer from one individual to another [16] and where the main problem is how to handle knowledge as a manageable object [17]. The focus on learning as action is distinctly separated and contrasted from viewing knowledge as an abstract object and learning as transmission, reception and storage of such objects. Instead, learning and knowing is action, rather than the mere result of acting. These actions are situated in the context of particular, concrete circumstances of everyday life [18]. Consequently knowledge is dependent on, and part of, the activities and situations in which it is produced. Taking this perspective on learning and knowing, we must pay interest to the situations of learning and the moments of knowing, exploring learning as a part of the context of acting.

If we look upon learning as taking place in the situations of participation rather than as cognitive change, new ways of conceptualizing learning and knowing are made available. Instead of focusing on finding true and exact definitions of learning we can start to explore the conditions of learning and knowing as part of practice, in this way focusing on the situations where knowledge plays an actual part in the lives of people. Consequently, learning can be understood as many different things such as learning to use a new tool in a specific situation, seeing ordinary things in new perspectives, as a change in which settings we are part of or even learning as a change in how others allow us to engage in collaborative activities [8]. When focus is changed from understanding learning going on in the mind of the learner to the situations of participation, new possibilities for understanding learning are made available.
The communities we take part in are part of a designed and artificial world, and we live in this world through and with these artifacts. Our actions are mediated through the artifacts we apply, artifacts that we have learned to master and appropriated through engagement in practice. This not only includes "physical” tools, but also (and particularly) intellectual ones, such as the concept of time, subtraction, and language. Involving ourselves in different practices, we learn not only how to use specific tools but also ways of talking and thinking.

Tools and practices sustain and reinforce each other. The practices are sustained or contested through our continuous involvement of artifacts. For instance, the police officer's note book say something about how competent police practice is achieved, the mobile phone of the salesman indicates what selling is about, and the consultants' time management system says something about how work is valued in that practice. The practice is remembered through the use of artifacts. In the use of tools lies the connection to the history of the community, helping us to know how things are or should be done, and in the use there is also the possibility to question how things are generally done [8]. The practice is sustained through the use of tools and changed through the rejection and invention of new tools, and the tools for mediating our actions are provided by and constructed in relation to the continuum of practice in which we partake [19], [20]. In this way the tools we apply and the practices sustained through the engagement of these tools are mutually sustaining each other. Only through the iterated use in a social collective can the tools obtain meaning, and only through seeing, hearing and talking about how tools are used can they be mastered. When we enter into, and participate in social practices, we familiarize ourselves with, and learn how to master artifacts that are considered relevant and valid in the specific practice. Such artifacts include intellectual tools such as discourses, perspectives, and skills. The skills we learn to master are in this way inherently defined and connected to the practice in which they are learned:

"Learning surgery, bicycle-riding or physics are inseparable from learning to be a surgeon, a cyclist or a physicist, respectively; the community is all.” [21 p. 772].

In this way learning and knowing are connected to and part of practice. For example, learning police work is about becoming an officer, and becoming an officer is about appropriating and applying the artifacts of the police. As talk is becoming the main tool applied in practice, learning a practice is about learning a way of talking.

To engage in everyday work is to continuously produce different representations of the past, the present and the future. These interpretations of work enable the workers to develop their knowledge in practice, and also allow them, as a collective, to revise and innovate how work is performed [10]. Studies of how knowledge is formed and shared at work, show how talking is the fundamental activity (e.g. [22], [23]). Through talking about the world with others we articulate our experiences and are in this way able to contrast them with conflicting perspectives of the world. In conversations, workers engage in practice, and learn to become competent practitioners [9]. In this way talking about work is essential for learning both to individuals as well as to the collective. It introduces 
newcomers, sustains and distributes knowledge in practice over time, as well as innovates the practice [8].

\section{B. IS - design for learning}

Information system (IS) design research is often prone to overemphasizing the technical artefact in the design process and thereby failing to account for the situated nature of the practices in to which the artefact is to be integrated and used [24]. Recent work that addresses this concern and views IS design activities as inherrently socio-cultural includes [25], [26], and [27]. Furthermore, in a paper from 2002, Markus, Majchrzak and Gasser [28] presented a model for IS design theory (ISDT) (based on the work of Walls et al. [29]), where they stated that an IS design theory should be rooted in a kernel theory that guides the elicitation of requirements, consequently transformed into principles for design and development.

The kernel theories used derive from different fields such as social theories of learning (e.g [30], [31], [32], [33]), diffusion theory and cognitive theories of e-learning [27], and cognitive model of media choice and Vygotskian views on learning [34]. Still even though there is a growing body of literature on ISDT for learning, there are two major challenges that needs further attention:

Firstly, there is a lack of pedagogical innovation in design practice. Jones and Gregor [27] make the observation, concerning their case, that " $\mathrm{A}$ major benefit of technology mediated learning, yet to be fully unleashed through this work, is the potential to develop innovative pedagogical practices."

Secondly, a central problem still to be bridged is the distance between a fairly generic and abstract design theory and the the specific contexts and content where theory is to be applied in actual design practice. Hardless [33] suggest that design concepts could be instrumental to that effect:

"Design concepts served the role as an intermediate conceptualization between design theory and concrete prototype. A design concept is here a collection of general ideas and principles for a type of CDS [Competence development system]. In other words, a definition of a particular type of learning intervention abstracted beyond specific instances or realizations based on the design concept.” [33]

Hence, design concepts are to be derived from, and evaluated against the design framework where the kernel theory generates requirements for the phenomenon design is intended to support and develop. Requirements are then transformed into design guidelines, and design concepts are derived from the design theory. Design concepts are realized into prototypes and systems in various practices and the system evaluation feeds back to design concepts and design theory. In the context of e-learning we believe there is a need for this type of intermediary level of abstraction in between educational practice and IS design theory.

However, the question of how to describe and frame a design concept still remains. A popular, yet criticized, approach to making design for e-learning more tangible is the idea of so called learning objects (see for example [35]). Where the idea is that chunks of information could be framed into pedagogically neutral, and reusable packages that could be combined to address any learning objective.
However, the idea of learning objects is in fundamental opposition to that of learning as situated in the particular sucumstances of learning. The concept of learning objects are dependent on the objects being "pedagogically neutral" [36], in that sense conceptually separating what is learned from the situation in which learning is taking place.

We advocate, that instead of focusing on learning objects that does not embrace the situated nature of work practice as a resource for neither design work nor learning, we should more actively use existing learning practices as an inspiration for the design of learning models.

\section{Designing Learning activities and Learning Models}

Within design of IT support for learning at work the dominant tradition is one where learning is understood as knowledge transfer from one individual to another [16] and where the main problem is how to handle knowledge as a manageable object [17]. However, when focus is changed from understanding learning going on in the mind of the learner to the situations of participation, new possibilities for understanding learning are made available. The communities we take part in are part of a designed and artificial world, and we live in this world through and with these artifacts. Our actions are mediated through the artifacts we apply, artifacts that we have learned to master and appropriated through engagement in practice. This not only includes "physical” tools, but also (and particularly) intellectual ones, such as the concept of time, subtraction, and language. Involving ourselves in different practices, we learn not only how to use specific tools but also ways of talking and thinking.

A design method for IS supported learning that is based on a social and practice based understanding of learning is challenging since the process of design essentially is difficult to align with a scientific process: "The scientific and analytic tools available to us are not designed to handle the real: at least not in any holistic ssense, because, from a design perspective, the real is a whole. Any new design is, by definition, too complex and rich to be completely understood during the process of creation. We cannot predict with accuracy how any real design will serve the world and, in turn, how it will change it." [37, pp. 45]. In this sense the process of building new IS support for learning at work is a messy process (in scientific measures), and it demands methods which are able to incorporate the specifics of the particular practice in which we want to make the change. Taking such a perspective it is obvious that we cannot design pedagogically neutral learning objects, neither can we design methods for learning that can be easily transferred between different practices. IS design for learning must be founded within the practice in question.

We also argue that such a perspective might help bridge descriptive and normative approaches to workplace learning and the theoretical dilemma that this stresses resonates with the call for approaches that promotes pedagogical innovations [27]. We do not suggest that learning activities should be adjusted according to different learning situations, which is one approach that have proven useful, rather we suggest that they should be designed based on studies of how learning is part of the workplace activities. This research is driven by the idea that the particular ways in which people go about to produce the knowledge they need to conduct their work 
can be exploited to enhance possibilities for learning. Such tacit models for learning are already adapted to the practice, they carry with them the practice approach to how new things should be, and can be learned. The basic premise of the method is to base the IS design for learning on how learning is actually taking place in the ordinary activities of the workers. As a result of a three year research project we argue that such learning models, consisting of a sequence of learning activities, could be instrumental in framing the didactics of the workplace.

In the next section we briefly outline the empirical foundations for our argument, and present an example of a learning model called the Competence kick-off.

\section{THE CASE}

The empirical material that underpins the argumentation of this paper stems from a collaboration research project called "Competence Management in Network Organisations” (CoMaNwO) where representatives from six SME:s participated in investigating and further exploring each organisations motivation for developing a learning and competence management infrastructure for their network activities. The project had a particular focus on the role of IT as a mediating tool for the establishment of such an infrastructure.

\section{A. The Case organization}

Networking Companies (NWC) is the oldest and most established network of business organizations within the four-city region, comprised of Trollhättan, Vänersborg, Uddevalla and Lysekil, in Sweden. The network organization consists of 40 companies of which a majority is suppliers to the automotive and technology industry of Western Sweden. The member organizations range from SME:s with under 50 employees to the leading industries of the region (Volvo Aero and Saab GM)

NWC was started for the purpose of enhancing the competitive strengths of the members by means of both business and competence development, Networking Companies has evolved into being a discussion partner, sounding board and logical meeting place for both established and start-up technology companies in West Sweden. The group is involved in collaborative projects with regional business development entities and with University West. Over the years, they have created relationships and close contacts between their corporate members and their supportive partner organizations. The goals of the network are to reach larger and more comprehensive marketing solutions, offer cutting edge competence within traditional as well as newly evolving business sectors, in addition to greater collaboration among corporate members. NWC hold regular meetings to which they invite opinion and corporate leaders of interest to their members for the purpose of creating deeper business relationships and contacts.The goals of NWC (quoted from network's homepage, http://www.networkingcompanies.se) are:

- Act as a discussion partner for the technology and automotive industry in the four-city region

- Broaden business contacts and create new business development opportunities

- Showcase the cutting edge competence of our corporate members
- Create the preconditions leading to comprehensive, system based industry solutions

\section{B. Project organization and data collection methods}

The CoMaNwO-project was a collaboration projects between the board of directors of NWC and Laboratorium for Interaction Technology (research group in Informatics at University West, UW). The network organization together with six corporate partners selected for this project constitute a representative selection of both SME:S and large corporations in the region. Each company is oriented towards frontline technological development and consequently identifies competence management as the primary challenge for the future. CoMaNwO is organized as a collaborative research project where six researchers from UW together with six members from the industrial firms constitute the project team.

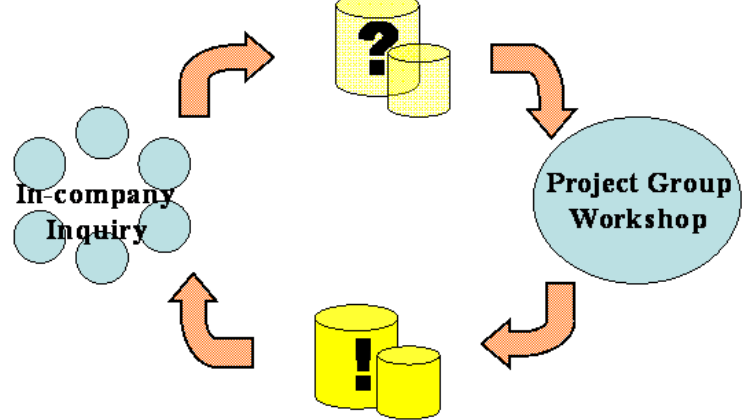

Figure 1. The Project workflow as an iterative collaborative circle

The overall organization of the project can be outlined as an iterative and collaborative circle with four stages in each rotation (fig. 1). The project model is partly inspired by canonical action research method (See for example [38]) In the first stage diagnosing is conducted through incompany meetings with observations, interviews, surveys and seminars at each participating organization. In the second stage tentative action planning is conducted by the research group, this is subsequently discussed and evaluated in a 2-day project group workshop with practitioners, researchers and sometimes external experts. The deliverables from such workshops are jointly agreed upon action plans which are then put into action at the network level. The data collected for this paper is the result of two repetitions of the collaborative circle. More specifically the data consist of:

- Six group interviews with representatives (3-5) from each firm, lasting approximately 1,5 hour each.

- Two joint workshops (2 days each) with round-table discussions on themes such as: What is competence? How can it be articulated and supported? What are the existing learning practices?

- Web survey that explores respondents' view on competence and competence processes on: (i) individual-, (ii) group-, (iii) company/management-, and (iv) network-level

\section{The Competence Kick-off - An Example}

The first learning model that was designed in the CoManWo project was called "Competence Kick-off" (CKO). As an example it illustrates how design work can capatilize on existing competence development practice, and at the same time further develop this practice to address problems and shortcomings expressed by the 
practitioners. Initially, the idea was a response to the fact that many of the participating practitioners expressed frustration over past experiences when having used external experts for introductions to new knowledge domains. The frustration related firstly to a mismatch between what was expected and what was delivered by the expert, or as expressed by one of the practitioners:

"Most times the so called experts fail to give you what you really need. Either their talk is too basic or they are far to advanced" (HR Manager)

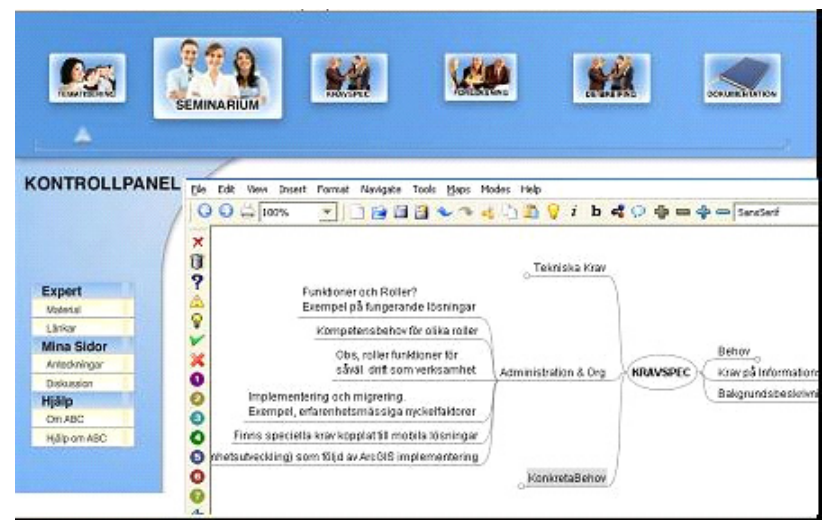

Figure 2. Mind-map tool for learning activity no two of the competence kick-off learning model.

Secondly, many of the practitioners stated that they often felt that the audience of an expert lecture or seminar was ill-prepared and consequently, it was often difficult to see that these activities left any persistent traces in the organization, even though the idea was that the people being sent to the lecture should subsequently pass on their new knowledge to colleagues in "pilot-seminars.". To address these shortcomings a learning model with six distinct learning activities were developed, each with specific pedagogical structure, situated content and appropriate IT-support. In the first step the title of the competence kick-off is set and advertised in the network. Participants enroll, and an expert is contacted and contracted. After having studied some introductory material, the learners gather for a moderated discussion seminar where the goals and knowledge levels of each participant is presented, discussed and negotiated resulting in a jointly agreed upon requirement specification that clearly states what themes and questions the expert should address. After negotiating the requirements with the expert, an interactive expert presentation is performed. Subsequently, the participants meet to evaluate and discuss the outcome, and how to proceed. Finally, the experiences are documented in a white-paper that could be distributed to other interested parties in the network, or could be used as support in pilot-seminars.

The Competence kick-off, and its six learning activities has been designed and re-designed through four loops of evaluations in three different settings with four different themes ("Digital Video" for a group of journalists, "Geographical Information Systems" for a network of public administrators, and "Organizational Culture” and "Business negotiations" for SME managers). The evaluations have generated several implications for design regarding for instance online-templates for the requirement specification document and the white paper, as well as a mind-mapping tool for framing, deconstructing and prioritizing the theme (fig. 1). The current synthesis of design implications for the competence kick-off learning model is summarized in the framework of table 1.

TABLE I. THE SIX LEARNING ACTIVITIES OF THE COMPETENCE KICK-OFF LEARNING MODEL

\begin{tabular}{|c|c|c|}
\hline $\begin{array}{l}\text { Sequence of } \\
\text { Learning } \\
\text { Activities }\end{array}$ & Content & IT-Functionality \\
\hline $\begin{array}{l}\text { 1. Introducing the } \\
\text { theme }\end{array}$ & $\begin{array}{l}\text { A title is set for the } \\
\text { CKO, and an expert } \\
\text { is contacted. } \\
\text { Participants work } \\
\text { with introductory } \\
\text { material }\end{array}$ & $\begin{array}{l}\text { Web-based } \\
\text { introductory texts } \\
\text { and/or video clips }\end{array}$ \\
\hline $\begin{array}{l}\text { 2. Framing and } \\
\text { Prioritizing }\end{array}$ & $\begin{array}{l}\text { Participants discuss } \\
\text { \& negotiate their } \\
\text { objectives and needs. } \\
\text { Thereby identifying } \\
\text { \& prioritizing core } \\
\text { questions and themes }\end{array}$ & $\begin{array}{l}\text { Computer } \\
\text { Conference System } \\
\text { or Video Conference } \\
\text { Graphical tool for } \\
\text { mind-mapping }\end{array}$ \\
\hline $\begin{array}{l}\text { 3. Requirement } \\
\text { Specification }\end{array}$ & $\begin{array}{l}\text { A formal document } \\
\text { that is negotiated } \\
\text { with the expert } \\
\text { regulating content } \\
\text { and goals for the } \\
\text { expert presentation }\end{array}$ & $\begin{array}{l}\text { Collaborative } \\
\text { authoring tool or } \\
\text { Blog }\end{array}$ \\
\hline $\begin{array}{c}\text { 4. Expert } \\
\text { Presentation }\end{array}$ & Interactive seminar & $\begin{array}{l}\text { Streaming video } \\
\text { suplemented with } \\
\text { tool for synchronous } \\
\text { text-communication }\end{array}$ \\
\hline 5. De-Briefing & $\begin{array}{l}\text { Group discussions } \\
\text { following up \& } \\
\text { evaluating the expert } \\
\text { seminar. }\end{array}$ & $\begin{array}{l}\text { Threaded discussion } \\
\text { forum or video- } \\
\text { conference }\end{array}$ \\
\hline 6. White Paper & $\begin{array}{l}\text { A jointly authored } \\
\text { document describing } \\
\text { the outcome of the } \\
\text { competence kick-off. } \\
\text { Intended also for } \\
\text { sharing with non- } \\
\text { participants. }\end{array}$ & $\begin{array}{l}\text { Collaborative } \\
\text { authoring tool or } \\
\text { Blog }\end{array}$ \\
\hline
\end{tabular}

\section{DISCUSSION}

The CKO-example illustrates how design work can be addressed at two levels that make sense to practitioners and that also allows for a practice based approach that capitalizes on the merits and flaws of existing learning practices. Practice can serve as inspiration both on the level of designing the learning model (where the goal is to address a concrete need rooted in practice), and also when dealing with each of the learning activities of which the learning model consists (where the overarching objective can be operationalized into pedagogical goals, roles and actions).

Experiences from the CoMaNwO project highlights that learning activities constitute a tangible unit of design which make sense to practitioners. A major strength of a learning activity is the fact that it is not pedagogically neutral. Instead, the design of learning activities relates to social, technological as well as pedagogical dimensions of practice. One might rightfully argue that the concept of learning activities is not new, it is a common term which has been used in both research, as well as in everyday discussions about how we learn. In this particular paper we want to use it, both to emphasize the situational qualities in different steps of a designed learning model, 
but also as an alternative to the idea of learning objects. An alternative that downplays learning as a neutral, content focused, based on transfer, and highlighting learning as activity, based in and dependent on the situation, and as part of a social continuum in which the learner takes part.

From a design perspective the learning activities is a help in breaking down the complex learning model into manageable chunks, but it also helps us to focus on the actual doings of the learner - it provides a use, and user centered approach to the design of IT support for learning. Still, design through a learning activity approach is not argued to be a silver bullet that automatically bridges the gap between descriptive and normative understandings of work practice, but merely an approach that allows us to deal with this in a sensible way. Furthermore, focusing the design work on learning models and learning activities does of course not exclude influence from theory. Still suitable IS design theories should guide and frame the design space.

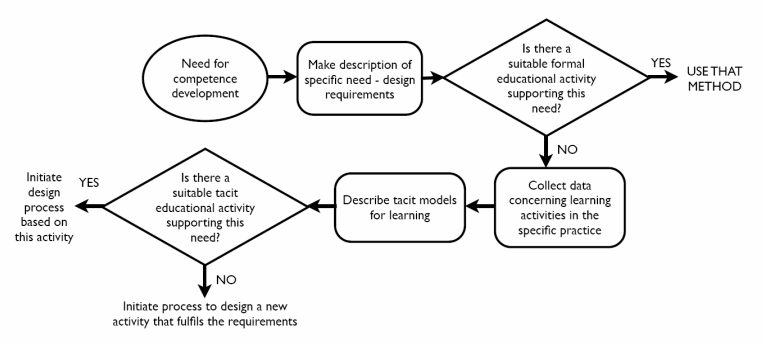

Figure 3. Workflow for practice.based design.

To summarize, What we are proposing is an alternative to strictly theory driven design of IT-supported learning activities in the work place through a more practice-based approach. In this case the tacit methods, ordinarily employed by the practitioners are the starting point for the design work. In fig. 3 the process up until concrete design efforts is needed, is described. The first step is that a need for learning is identified. This can be done in various ways, by management, practitioners, etc. After this the organization looks into already formalized forms for learning, and determines if there is a method already available that might be suitable. In that case this method ideally is used. However, it is likely that new needs, and new situations for knowing, trigger a need for new methods. In this case we need to look into the methods already tacitly employed by the practitioners. There might be a possibility to exploit these, something which in turn starts a process of designing such an activity (for discussion on this, see [39]). If there are not any available suitable methods, innovation is needed. It is then necessary to look to other sources for inspiration than the practice itself. In this case learning theories, experiences from other practices (such as for example school) might be of use.

The figure might give the impression that this can be understood as an instrumental process, that depends on just following a number of steps. This is not the case. In each of the steps different expertise is necessary. This is something that often characterizes the complex design process. Professional judgment and actions is needed for such steps as to identify the need for learning, to supervise the activities, to study how learning is taking place in the practice.

\section{CONCLUSIONS}

The paper set out to address the inherent conflict between descriptive and normative approaches to workplace learning. Through presenting and discussing a practice based approach where design is focused on learning models and learning activities we have shown how this can be done. The Competence Kick-off example highlights how the didactics of the workplace can be captured and reified into a learning model that is integrated into everyday practice.

\section{ACKNOWLEDGMENT}

Thanks to all engaged members of the Networking Companies that contributed to workshops and design work. Especially we want to thank Lena Skarsjö (coordinator for NWC) who seams to possess endless energy resources when it comes to action research.

\section{REFERENCES}

[1] Castells, M. (1996). Rise of the Network Society: The Information Age: Economy, Society and Culture, Blackwell Publishers, Inc. Cambridge, MA, USA.

[2] Florida, R. L. (2002). The Rise of the Creative Class: And How It's Transforming Work, Leisure, Community and Everyday Life, Basic Books.

[3] Malone, T. W. (2004). The Future of Work: How the New Order of Business Will Shape Your Organization, Your Management Style, and Your Life, Harvard Business School Press.

[4] Alavi, M. and D. E. Leidner (2001). "Knowledge Management and Knowledge Management Systems: Conceptual Foundations and Research Issues." MIS Quarterly 25(1): 107-136.

[5] Senge, P. M. (1990). The Fifth Discipline: The Art and Practice of the Learning Organization. New York, Doubleday Dell Publication Group.

[6] Nonaka, I. and H. Takeuchi (1995). The Knowledge Creating Company, Oxford, Oxford University Press.

[7] Argyris, C. (1991). "Teaching Smart People How to Learn." Reflections 4(2): 4-15.

[8] Wenger, E. (1998). Communities of Practice - Learning, Meaning, and Identity. Cambridge, UK, Cambridge University Press.

[9] Lave, J. and E. Wenger (1991). Situated learning - Legitimate peripheral participation. Cambridge, Cambridge University Press.

[10] Orr, J. E. (1996). Talking About Machines - An Ethnography of a Modern Job. Ithaka, New York, US, Cornell Unicersity Press.

[11] Brown, J. S. and P. Duguid (1991). "Organizational Learning and Communities-of-Practice: Toward a Unified View of Working, Learning and Innovation." Organization Science 2(1): 40-56.

[12] Schön, D. A. (1983). The Reflective Practitioner - How Professionals Think in Action, Basic Books, Inc.

[13] Marsick, V. J. and K. E. Watkins (1990). Informal and Incidental Learning in the Workplace (International Perspectives on Adult and Continuing Education), Routledge.

[14] Billet, S. (2002). "Critiquing workplace learning discourses: Participation and continuity at work." Studies in the Education of Adults 34(1): 56-67.

[15] Fischer, G. (2000). "Lifelong Learning - More Than Training." Journal of Interactive Learning Research 11(3): 265-294.

[16] Shultze, U. and D. E. Leidner (2002). "Studying Knowledge Management in Information Systems Research: Discourses and Theoretical Assumptions." MIS Quarterly 26(3): 213-2242.

[17] Alvesson, M. and D. Kärrman (2001). "Odd Couple: Making Sense of the Curious Concept of Knowledge Management." Journal of Management Studies 38(7): 995-1018. 
[18] Suchman, L. (1987). Plans and Situated Actions - The Problem of human-machine communication. Cambridge, Cambridge University Press.

[19] Wertsch, J. V. (1991). Voices of the Mind: A Sociocultural Approach to Mediated Action, Harvard University Press.

[20] Wertsch, J. V. (1998). Mind As Action, Oxford University Press, USA.

[21] Khan, T. M., J. E. M. Mitchell, et al. (1998). "Situated learning using descriptive models." International Journal of HumanComputers Studies 49(6): 771-796.

[22] Drew, P. and J. Heritage (1992). Talk at Work: Interaction in Institutional Settings. Cambridge, UK, Cambridge University Press.

[23] Button, G. (1991). Conversation-in-a-series. Talk and Social Structure. B. D. and Z. D. H., Polity Press, Cambridge: 251-277.

[24] McKay, J., \& Marshall, P. (2005). A review of design science in information systems. Paper presented at the 16th Australasian Conference on Information Systems, Sydney, Australia.

[25] Carlsson, S. (2005). Developing Information Systems Design Knowledge: A Critical Realist Perspective. The Electronic Journal of Business Research Methodology, 3(2), 93-102.

[26] Boland, R. J., \& Lyytinen, K. (2004). Information systems research as design: identity, process and narrative. In B. Kaplan, D. Truex, D. Wastell, T. Wood-Harper \& J. DeGross (Eds.), Information systems research: Relevant theory and informed practice. Boston: Kluwer Academic Publishers.

[27] D. Jones, D. \& Gregor, S. (2006) The formulation of an Information Systems Design Theory for e-learning

[28] Markus, M. L., Majchrzak, A. \& Gasser, L. (2002). A Design Theory for Systems that Support Emergent Knowledge Processes. Management Information Systems Quarterly, 26 (3), 179-212.

[29] Walls, J. G., Widmeyer, G. R. \& El Sawy, O. A. (1992). Building an Information System Design Theory for Vigilant EIS, Information Systems Research 3 (1), 36-59.

[30] Herrington, J. \& Oliver, R. (1995). Critical Characteristics of Situated Learning: Implications for the Instructional Design of Multimedia, in Pearce, J. and Ellis, A. (Eds.). Learning With Technology, 235-262, Parkville, Victoria: University of Melbourne.

[31] Herrington, A. \& Herrington, J. (2006). Authentic learning environments in higher education. Hershey, PA: Information Science Publishing.

[32] Hung, D. \& Chen, D. (2001). Situated Cognition, Vygotskian Thought and Learning from the Communities of Practice Perspective: Implications for the Design of Web-Based ELearning. Education Media International, 38 (1), 3-12.

[33] Hardless, C. (2005). Designing Competence Development Systems, Doctorial dissertation, Department of Informatics, Gothenburg University, Sweden. 2005
[34] Hrastinski, S. (2007) Participating in Synchronous Online Education, Doctoral Thesis, Lund Studies in Informatics No. 6

[35] Hodgins, W., H. (2002) The future of Learning Objects, etechnologies in engineering education: Learning outcomes providing Future Possibilities, Vol. P1, Article 11

[36] Friesen, N (2004) Three Objections to Learning Objects and Elearning Standards in: McGreal, R. (Ed.). 2004. Online Education Using Learning Objects. London: Routledge, pp. 59-70

[37] Nelson, H. G. and E. Stolterman (2003). The Design Way: Intentional Change in an Unpredictable World : Foundations and Fundamentals of Design Competence. Englewood Cliffs, NJ, Educational Technology Publications.

[38] Lindgren, R., O. Henfridsson, and U. Schultze (2004) Design Principles for Competence Management Systems: A Synthesis of an Action Research Study, MIS Quarterly Vol. 28 No. 3, pp. 435472 September.

[39] Lundin, J. (2004). "Designing Computer Supported Collaborative Learning Activities for Specific Contexts." Psychnology 2(2): 205-228.

\section{AUTHORS}

J. Lundin is with the department of Applied IT, at University of Gothenburg, PO Box 100, SE-405 30 Gothenburg, SWEDEN, and is working as a guest researcher at University West Sweden (e-mail: johan.lundin@gu.se).

L. Svensson is the director of Forum for WorkIntegrated Learning, at University West, G Melins g. 2,, SE-461 86 Trollhattan, SWEDEN. He is also scientific leader for the multi disciplinary research program "Learning in and for the new workplace" at University West. (e-mail: lars.svensson@hv.se).

U. Lundh-Snis is with the department of Economy and IT at University West, G Melins g. 2,, SE-461 86 Trollhattan, SWEDEN. She is alsothe research director of Laboratorium for Interaction Technology at University West (e-mail: ulrika.snis@hv.se).

L. Pareto is with the department of Economy and IT at University West, G Melins g. 2,, SE-461 86 Trollhattan, SWEDEN. Lena is currently program manager for Digital Media at University West (e-mail: lena.pareto@hv.se).).

This work was sponsored by the European Union Structure Fund (area 2 West Sweden), and the Swedish Knowledge Foundation.

Manuscript received 15 July 2008. Published as submitted by the author(s). 